\title{
Komunikasi Verbal yang Dilakukan oleh Jubir Covid 19 di Indonesia
}

\author{
Qolbiya Sakinah*, Nia Kurniati Syam, Chairiawaty
}

Prodi Komunikasi Penyiaran Islam, Fakultas Dakwah, Universitas Islam Bandung, Indonesia.

*qolbiasakinah1@gmail.com, nia.kurniati@unisba.ac.id, chairiawati@unisba.ac.id

\begin{abstract}
Communication is a very basic thing in human life, even communication has become a phenomenon for the formation of a society or community that is integrated by information, where each individual in the community itself shares information (Information sharing) to achieve common goals. . In simple terms, communication can occur when there is a similarity between the message and the person receiving the message. In providing information for the task force to accelerate the handling of covid 19 in Indonesia, Achmad Yurianto gave a statement "the rich and the poor" which could cause controversy in a press conference regarding the handling of covid 19. For a Muslim, in speaking, he certainly uses good ethics communication, such as ethics in an Islamic perspective, namely Qoulan Sadidan, Qoulan Balighan, Qoulan Masyura, Qoulan Layyina, Qoulan Karima, Qoulan Ma'rifa. Based on this phenomenon, the researcher conducted a study entitled Verbal Communications Done by The Covid 19 In Indonesia (Verbal Communication Discourse Analysis in Islamic Perspective Online). This qualitative research uses a descriptive study with discourse analysis techniques from an Islamic perspective. This study aims to determine the use of diction, phrases, sentences in verbal communication carried out by the Covid 19 spokespersons in Indonesia in an Islamic perspective. The results obtained from this study are (1) 34 diction which are included in the Islamic perspective. (2) 37 phrases included in the Islamic perspective. (3) 39 sentences that fall into the Islamic perspective.
\end{abstract}

\section{Keywords: Verbal Communication, Discourse Analysis, Islamic Perspective.}

Abstrak. Komunikasi merupakan suatu hal yang sangat mendasar dalam kehidupan manusia, bahkan komunikasi telah menjadi suatu fenomena bagi terbentuknya suatu masyarakat atau komunitas yang terintegrasi oleh informasi, di mana masing-masing individu di dalam masyarakat itu sendiri saling berbagi informasi (Information sharing) untuk mencapai tujuan bersama. Secara sederhana komunikasi dapat terjadi apabila ada kesamaan antara pesan dan orang yang menerima pesan. Dalam memberikan informasi jubir gugus tugas percepatan penanganan covid 19 di Indonesia Achmad Yurianto memberikan pernyataan "si kaya dan si miskin" yang dapat menimbulkan kontroversi dalam suatu konferensi pers dalam penanganan covid 19. Bagi seorang muslim seharusnya dalam berbicara, beliau tentunya menggunakan etika yang baik dalam berkomunikasi, seperti etika dalam perspektif Islam, yaitu Qoulan Sadidan, Qoulan Balighan, Qoulan Masyura, Qoulan Layyina, Qoulan Karima, Qoulan Ma'rifa. Berdasarkan fenomena tersebut, peneliti melakukan penelitian dengan judul Komunikasi Verbal yang Dilakukan oleh Jubir Covid 19 di Indonesia (Analisis Wacana Komunikasi Verbal Dalam Perspektif Islam secara Online). Penelitian kualitatif ini menggunakan studi deskriptif dengan teknik analisis wacana dalam perspektif Islam. Penelitian ini bertujuan untuk mengetahui penggunaan diksi, frase, kalimat dalam komunikasi verbal yang dilakukan oleh jubir covid 19 di Indonesia dalam persepektif Islam. Hasil yang didapatkan dari penelitian ini adalah (1) 34 diksi yang termasuk ke dalam perspektif Islam. (2) 37 frase yang termasuk ke dalam perspektif Islam. (3) 39 kalimat yang termasuk ke dalam perspektif Islam.

Kata Kunci: Komunikasi Verbal, Analisis Wacana, Perspektif Islam. 


\section{A. Pendahuluan}

Komunikasi merupakan suatu hal yang sangat mendasar dalam kehidupan manusia, bahkan komunikasi telah menjadi suatu fenomena bagi terbentuknya suatu masyarakat atau komunitas yang terintegrasi oleh informasi, di mana masing-masing individu di dalam masyarakat itu sendiri saling berbagi informasi (Information sharing) untuk mencapai tujuan bersama. Komunikasi juga dipahami sebagai bentuk komunikasi interaksi, yaitu komunikasi dengan proses sebab-akibat atau aksi reaksi yang arahnya bergantian. Dalam konteks ini, komunikasi melibatkan komunikator yang menyampaikan pesan, baik secara verbal maupun nonverbal kepada komunikan yang langsung memberikan respon baik berupa verbal dan nonverbal secara aktif, dinamis dan timbal balik. Salah satu potensi manusia yang telah ada semenjak ia lahir ialah berkomunikasi. Bila ditinjau dari perspektif agama, alasan mengapa manusia berkomunikasi ialah karena Allah sendiri yang telah mengajarkan manusia untuk berkomunikasi dengan menggunakan akal dan kemampuan berbahasa yang dianugerahkan-Nya. Seperti yang dijelaskan dalam Al-Quran surat Ar-Rahman ayat 1-4:

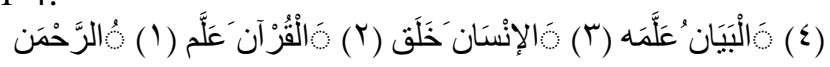

Artinya: (1) (Tuhan) yang Maha Pemurah. (2) Yang telah mengajarkan Al-Quran. (3) Dia menciptakan manusia. (4) Mengajarnya pandai berbicara.

Komunikasi tidak akan pernah lepas dari kehidupan manusia, selain karena kebutuhan hidup sehari-hari, komunikasi dapat membantu manusia dalam segala hal, seperti jual beli, interaksi sesama manusia. Komunikasi sebagai proses interaksi antara sesama manusia akan terus mengalami perubahan dan perkembangan terlebih pada tata cara penyampaian yang digunakan manusia tersebut dalam menyampaikan pesan. Dalam memberikan informasi jubir gugus tugas percepatan penanganan covid 19 di Indonesia Achmad Yurianto memberikan pernyataan "Si kaya dan si miskin" yang dapat menimbulkan kontroversi dalam suatu konferensi pers dalam penanganan covid 19. Dari penyataan secara lengkapnya "saya meminta orang kaya peduli sama orang yang harus bekerja harian di luar rumah, mereka rentan sakit." Dan juga "saya ilustrasikan banyak orang kaya yang membantu kebutuhan sembako harian orang miskin, sehingga mereka tidak perlu lagi keluar rumah untuk mengurangi resiko ketularan penyakit." Dalam beberapa kutipan itulah maka akan menimbulkan konroversi yang mengakibatkan adanya diskriminasi. Berkaitan dengan etika komunikasi tersebut, bagaimanapun juga seorang muslim harus berpedoman pada sumber utama Islam, yakni Al-Qur'an dan Sunnah Nabi. Dalam berkomunikasi kita harus mencontoh bagaimana Rasulullah SAW dalam berbicara, beliau tentunya menggunakan etika yang baik dalam berkomunikasi, seperti etika dalam perspektif Islam, yaitu Qoulan Sadidan, Qoulan Balighan, Qoulan Masyura, Qoulan Layyina, Qoulan Karima, Qoulan Ma'rifa.

Berdasarkan latar belakang di atas, peneliti akan mengkaji mengenai teknik komunikasi yang dilakukan oleh jubir Covid 19 di Indonesia, melalui media sosial dari mulai bulan maret hingga mei 2020.

\section{B. Landasan Teori}

\section{Komunikasi}

Kata "komunikasi" berasal dari bahasa Latin, communication, yang berarti 'pemberitahuan' atau 'pertukaran pikiran'. Secara garis besar dalam proses komunikasi, harus ada unsur-unsur kesamaan makna agar terjadi suatu pertukaran pikiran dan pengertian antara komunikasi (penyebar pesan) dan komunikan penerima pesan.

\section{Komunikasi Verbal}

Komunikasi verbal adalah komunikasi yang menggunakan simbol-simbol dan kata-kata, baik yang dinyatakan secara oral atau lisan maupun tulisan. Komunikasi verbal yaitu komunikasi yang dalam menyampaikan peannya dengan menggunakan lisan dan tulisan. Menurut Paulette J. Thomas, Komunikasi verbal adalah penyampaian dan penerimaan pesan dengan menggunakan bahasa lisan dan tulisan. Sementara, lambang verbal merupakan semua lambang yang digunakan untuk menjelaskan pesan-pesan dengan memanfaatkan kata-kata (bahasa). Komunikasi verbal 
yaitu penerimaan sistem syaraf seseorang kepada sistem syaraf orang lain dengan maksud untuk menghasilkan sebuah makna serupa dengan yang ada dalam pikiran si pengirim, dengan menggunakan kata-kata yang merupakan unsur-unsur dasar bahasa.

1. Klasifikasi Komunikasi Verbal

- Komunikasi verbal melalui lisan dapat diartikan sebagai suatu proses dimana seorang berinteraksi secara lisan dengan pendengar untuk mempengaruhi tingkah laku penerima. Komunikasi verbal melalui lisan dapat dilakukan secara langsung bertatap muka antara komunikator dengan komunikan, seperti berpidato atau ceramah. Selain itu juga, komunikasi verbal melalui lisan dapat dilakukan dengan menggunakan media, contoh seseorang yang bercakap-cakap melalui telepon.

- Komunikasi verbal melalui tulisan dilakukan dengan secaratidak langsung antara komunikator dengan komunikan. Proses penyampaian informasi yang dilakukan dengan menggunakan berupa media surat, lukisan, gambar, grafik dan lain-lain.

2. Tujuan Komunikasi Verbal

Adapun tujuan menggunakannya komunikasi verbal (lisan dan tulisan antara lain.

- Penyampain penjelasan, pemberitahuan, arahan, dan lain sebagainya,

- Presentasi penjualan dihadapan para audien,

- Penyelenggaraan rapat,

- Wawancara dengan orang lain,

- Pemasaran melalui telepon, dsb.

\section{Analisis Wacana}

\section{Definisi Wacana}

Kata wacana banyak digunakan oleh berbagai ilmu pengetahuan salah satunya Ilmu Komunikasi. Secara spesifik pengertian, definisi dan batasan istilah wacana sangat beragam. Hal tersebut disebabkan oleh perbedaan lingkup dan disiplin ilmu yang memakai istilah wacana tersebut.

\section{Komunikasi Dalam Perspektif Islam}

Dalam Alquran dapat ditemui tuntunan yang sangat baik sebagai etika dalam berkomunikasi ini yakni:

3. Qaulan Sadidan (perkataan benar, lurus, jujur).

Qaulan sadidan artinya pembicaraan yang benar, jujur, lurus, tidak bohong, tidak berbelitbelit. Prinsip komunikasi yang pertama menurut Alquran adalah berkata yang benar.

4. Qoulan Balighan (perkataan yang membekas pada jiwa, tepat sasaran, komunikatif, mudah dimengerti).

Kata "baligh" dalam bahasa Arab artinya sampai, mengenai sasaran atau mencapai tujuan. Apabila dikaitkan dengan qawl (ucapan atau komunikasi), "baligh" berarti fasih, jelas maknanya, terang, tepat menggunakan apa yang dikehendaki. Oleh karena itu prinsip qaulan balighan dapat diterjemahkan sebagai prinsip komunikasi yang efektif.

5. Qoulan Maysura (perkataan yang ringan).

Secara terminologi qaulan maisura berarti mudah. Lebih lanjut dalam komunikasi dakwah dengan menggunakan qulan maisura dapat diartikan bahwa menyampaikan pesan dakwah, $d a$ " $i$ harus menggunakan bahasa yang "ringan", "sederhana" dan "pantas" atau yang "mudah diterima" oleh mad" $u$ secara spontan tanpa harus melalui pemikiran yang berat.

6. Qoulan Layyina (perkataan yang lemah lembut).

Komunikasi yang tidak mendapat sambutan yang baik dari orang lain adalah komunikasi yang dibarengi dengan sikap dan perilaku yang menakutkan dan dengan nada bicara yang tinggi dan emosional. Cara berkomunikasi seperti ini selain kurang menghargai orang lain, juga tidak etis dalam pandangan agama. Dalam perspektif komunikasi, komunikasi yang demikian, selain tidak komunikatif, juga membuat komunikan mengambil jarak disebabkan adanya perasaan takut di dalamd irinya. 
7. Qoulan Karima (perkataan yang mulia).

Qaulan karimah adalah perkataan yang mulia, dibarengi dengan rasa hormat dan mengagungkan, enak didengar, lemah-lembut, dan bertatakrama.

8. Qoulan Ma'rufa (Perkataan yang pantas)

Qaulan ma'rufa dapat diterjemahkan dengan ungkapan yang pantas. Kata ma'rufa berbentuk isim maf'ul yang berasal dari madhinya, 'arafa. Salah satu pengertian mar'ufa secara etimologis adalah al-khair atau al-ihsan, yang berarti yang baik-baik. Jadi qoulan ma'rufa mengandung pengertian perkataan atau ungkapan yang baik dan pantas.

\section{Hasil Penelitian dan Pembahasan}

Hasil penelitian berdasarkan transkip wacana dari bulan Maret-Mei 2020 didapatkan beberapa diksi, frase, kalimat berdasarkan perspektif Islam sebagai berikut.

Tabel 1. Diksi, Frase, Kalimat Berdasarkan Perspektif Islam pada Transkip Wacana dari Bulan Maret-Mei 2020

\begin{tabular}{|l|c|c|c|c|c|c|c|}
\hline $\begin{array}{l}\mathbf{N} \\
\mathbf{0}\end{array}$ & $\begin{array}{c}\text { Etika } \\
\text { Komunikas } \\
\text { i Islam }\end{array}$ & Diksi & $\begin{array}{c}\text { Persentas } \\
\mathbf{e}\end{array}$ & Frase & $\begin{array}{c}\text { Persentas } \\
\mathbf{e}\end{array}$ & $\begin{array}{l}\text { Kalima } \\
\mathbf{t}\end{array}$ & $\begin{array}{c}\text { Persentas } \\
\mathbf{e}\end{array}$ \\
\hline 1. & $\begin{array}{c}\text { Qoulan } \\
\text { Sadidan }\end{array}$ & 11 & $32 \%$ & 11 & $30 \%$ & 11 & $28 \%$ \\
\hline 2. & $\begin{array}{c}\text { Qoulan } \\
\text { Balighan }\end{array}$ & 8 & $23 \%$ & 10 & $27 \%$ & 11 & $28 \%$ \\
\hline 3. & $\begin{array}{c}\text { Qoulan } \\
\text { Masyura }\end{array}$ & 5 & $15 \%$ & 8 & $22 \%$ & 7 & $18 \%$ \\
\hline 4. & $\begin{array}{c}\text { Qoulan } \\
\text { Layyina }\end{array}$ & 4 & $12 \%$ & 3 & $8 \%$ & 3 & $8 \%$ \\
\hline 5. & $\begin{array}{c}\text { Qoulan } \\
\text { Karima }\end{array}$ & 3 & $9 \%$ & 2 & $5 \%$ & 2 & $5 \%$ \\
\hline 6. & $\begin{array}{c}\text { Qoulan } \\
\text { Ma'rufa }\end{array}$ & 3 & $9 \%$ & 3 & $8 \%$ & 5 & $13 \%$ \\
\hline & $\begin{array}{c}\text { Jumla } \\
\text { h }\end{array}$ & $\begin{array}{c}\text { Diks } \\
\text { Dik }\end{array}$ & $100 \%$ & $\begin{array}{c}\text { Fras } \\
\mathrm{e} \\
37\end{array}$ & $100 \%$ & $\begin{array}{c}\text { Kalima } \\
\text { t } 39\end{array}$ & $100 \%$ \\
\hline
\end{tabular}

Penggunaan Diksi dalam komunikasi verbal yang dilakukan oleh jubir gugus tugas percepatan penanganan Covid 19 di Indonesia dalam perspektif Islam.

Diantara semua diksi ini yang termasuk kedalam perspektif Islam yang paling banyak disebutkan yaitu diksi yang termasuk kedalam Qoulan Sadidan yang berjumlah 11 (Sebelas) kata, lalu Qoulan Balighan berjumlah 8 (Delapan) kata, Qoulan Masyura 5 (Lima) kata, Qoulan Layyina 4 (Empat) kata, Qoulan Karima 3 (Tiga) kata, dan yang paling sedikit yaitu Qoulan Ma'rufa yaitu hanya 3 (Tiga) kata. Pada diksi ini mencerminkan bahwa informasi yang diberikan oleh 
jubir covid 19 dalam mengungkapkan fakta atau bukti adalah Sadida atau jujur. Banyak kata yang diungakapkan sesuai dengan fakta yang ada.

\section{Penggunaan frase dalam komunikasi verbal yang dilakukan oleh jubir gugus tugas percepatan penanganan Covid 19 di Indonesia dalam perspektif Islam.}

Dalam frase yang termasuk kedalam perspektif Islam yang paling banyak disebutkan yaitu Qoulan Sadida yang berjumlah 11 (Sebelas) frase, Qoulan balighan yang berjumlah 10 (Sepuluh) frase, Qoulan Masyura 8 (Delapan) frase, Qoulan Layyina dan Qoulan Ma'rufa memiliki jumlah yang sama yaitu berjumlah 3 (Tiga) frase, dan yang paling sedikit yaitu Qoulan Karima hanya berjumlah 2 (Dua) frase. Sama halnya dengan diksi pada frasepun jubir covid 19 lebih banyak mengungkapan frase yang termasuk ke dalam Qoulan Sadida dengan banyak menggunakan kata-kata yang jujur dan benar sesuai dengan fakta yang ada.

\section{Penggunaan kalimat dalam komunikasi verbal yang dilakukan oleh jubir gugus tugas percepatan penanganan Covid 19 di Indonesia dalam perspektif Islam.}

Dalam kalimat yang termasuk kedalam perspektif islam memiliki jumlah tertinggi yang sama yaitu terdapat pada Qoulan Sadida yang berjumlah 11 (Sebelas) kalimat dan Qoulan Balighan yang berjumlah 11 (Sebelas) kalimat. Setelah Qoulan Sadidan dan Qoulan Balighan yaitu Qoulan Masyura memiliki 7 (Tujuh) kalimat, Qoulan Ma'rufa 5 (Lima) kalimat, Qoulan Layyina 3 (Tiga) kalimat, dan yang paling sedikit yaitu Qoulan Karima berjumlah 2 (Dua) kalimat. Sama halnya dengan diksi dan frase pada kalimat pun jubir covid 19 lebih banyak menggunakan Qoulan Sadida yang memberikan ungkapan secara jujur dan tidak berbohong, namun di dalam kalimat juga Qoulan Balighan mendominasi dari Qoulan yang lainnya karena dalam laikmat-kalimat yang diungkapkan oleh jubir juga termasuk tepat sasaran yaitu objek mereka yaitu masyarakat dengan menggunakan bahasa yang mudah dimengerti sehingga masyarakat mematuhi aturan yang diberikan oleh pemerintah.

\section{Kesimpulan}

1. Penggunaan diksi dalam komunikasi verbal yang dilakukan oleh jubir gugus tugas percepatan penanganan covid 19 di Indonesia dalam pesepektif Islam berjumlah 34 kata. Diksi tersebut terbagi menjadi 11 kata Qoulan Sadidan, 8 kata Qoulan Balighan, 5 kata Qoulan Masyura, 4 kata Qoulan Layyina, 3 kata Qoulan Karima, dan yang paling sedikit yaitu Qoulan Ma'rufa yaitu hanya 3 kata. Pengunaan diksi ini mencerminkan bahwa informasi yang diberikan oleh jubir covid 19 dalam mengungkapkan fakta atau bukti adalah Sadida atau jujur. Banyak kata yang diungakapkan sesuai dengan fakta yang ada.

2. Penggunaan Frase dalam komunikasi verbal yang dilakukan oleh jubir gugus tugas percepatan penanganan covid 19 di Indonesia dalam pesepektif Islam berjumlah 37 frase yaitu 11 frase Qoulan Sadida, 10 frase Qoulan balighan, 8 frase Qoulan Masyura,3 frase Qoulan Layyina dan 3 frase Qoulan Ma'rufa, dan yang paling sedikit yaitu Qoulan Karima hanya berjumlah 2 frase. Sama halnya dengan diksi pada frase pun lebih banyak mengungkapan frase yang termasuk ke dalam Qoulan Sadida dengan banyak menggunakan kata-kata yang jujur dan benar sesuai dengan fakta yang ada.

3. Penggunaan kalimat dalam komunikasi verbal yang dilakukan oleh jubir gugus tugas percepatan penanganan Covid 19 di Indonesia dalam perspektif Islam. Penulis menemukan 39 kalimat yang termasuk dalam perspektif Islam. Dalam kalimat yang termasuk kedalam perspektif Islam memiliki jumlah tertinggi yang sama yaitu terdapat pada 11 kalimat Qoulan Sadida, 11 kalimat Qoulan Balighan, 7 kalimat Qoulan Masyura, 5 kalimat Qoulan Ma'rufa, 3 kalimat Qoulan Layyina, dan yang paling sedikit yaitu Qoulan Karima berjumlah 2 kalimat. Sama halnya dengan diksi dan frase pada kalimat pun jubir covid 19 lebih banyak menggunakan Qoulan Sadida yang memberikan ungkapan secara jujur dan tidak berbohong, namun di dalam kalimat juga Qoulan Balighan mendominasi dari Qoulan yang lainnya karena dalam kalimat-kalimat yang diungkapkan oleh jubir juga termasuk tepat sasaran yaitu objek mereka yaitu masyarakat dengan menggunakan bahasa yang mudah dimengerti sehingga masyarakat mematuhi 
6 | Qolbiya Sakinah, et al.

aturan yang diberikan oleh pemerintah.

\section{Daftar Pustaka}

[1] Deddy Mulyana. (2001). Prinsip-Prinsip Dasar Pengantar, Bandung: PT. Remaja Rosdakarya

[2] Eriyanto dalam buku Aris Badara. (2012) . Analisis Wacana: Teori Metode dan Penerapannya dalam Wacana, Jakarta: Kencana Prenada Media Group.

[3] Riswanto Hidayat, Komunikasi Verbal, www. Wordpress.com dakses tanggal 4 April 2011

[4] Roudhonah. (2007) . Ilmu Komunikasi, jakarta: Kerjasama Lembaga Penelitian UIN Jakarta dan Jakarta Presss

[5] Thomas Tokan P. (2016) . Komunikasi Politik, jakarta:PTGramedia Pustaka

[6] Ujang Saefullah. (2013). Kapita Selekta Komunikasi Pendekatan Budaya dan Agama, Bandung: Simbiosa Rekatama 